\title{
In Vitro Evaluation of the Virucidal Activity of Different Povidone-Iodine Formulations Against Murine and Human Coronaviruses
}

\author{
Manjunath Shet (D) - Rosa Hong (D) - David Igo (D) - Marc Cataldo (D) · \\ Sailaja Bhaskar (D)
}

Received: July 27, 2021 / Accepted: September 13, 2021 / Published online: September 28, 2021

(C) The Author(s) 2021

\begin{abstract}
Introduction: Polyvinylpyrrolidone-iodine (PVP-I) demonstrates broad-spectrum anti-infective activity and is available in different formulations for oral rinse and topical use in medical and personal care settings. The novel severe acute respiratory syndrome coronavirus 2 (SARS-CoV-2) has underscored the need to supplement available preventive strategies.

Methods: We assessed virucidal activity of PVPI formulations, including $0.5 \%(\mathrm{w} / \mathrm{v})$ solution, $5.0 \%(\mathrm{w} / \mathrm{v})$ solution, $7.5 \%(\mathrm{w} / \mathrm{v})$ scrub, and $10.0 \%(\mathrm{w} / \mathrm{v})$ solution, versus placebos when
\end{abstract}

M. Shet · D. Igo - S. Bhaskar

Imbrium Therapeutics, 201 Tresser Blvd, Stamford,

CT 06901, USA

M. Shet

e-mail: manjunath.shet@imbriumthera.com

D. Igo

e-mail: david.igo@imbriumthera.com

S. Bhaskar

e-mail: sailaja.bhaskar@imbriumthera.com

R. Hong

Avrio Health L.P., 201 Tresser Blvd, Stamford, CT 06901, USA

e-mail: rosa.hong@avriohealth.com

M. Cataldo $(\square)$

Purdue Pharma L.P., 201 Tresser Blvd, Stamford, CT 06901, USA

e-mail: marc.cataldo@pharma.com challenged with coronaviruses in two in vitro studies. Murine coronavirus strain A59 (American Type Culture Collection [ATCC ${ }^{\circledR}$ VR$764^{\mathrm{TM}}$ ), human coronavirus strain OC43 (ZeptoMetrix Corp. \#0810024CF), human coronavirus strain NL63 (ZeptoMetrix Corp. \#0810228CF), and human coronavirus strain 229E (ATCC $^{\circledR}$ VR-740 ${ }^{\mathrm{TM}}$ ) were used as surrogates for SARS-CoV-2. Both studies used the American Society for Testing and Materials in vitro time-kill method.

Results: All active PVP-I formulations in study 1 demonstrated virucidal activity at $15 \mathrm{~s}$, with mean $\log _{10}$ reduction of greater than 4.56 or greater than $99.99 \%$ inactivation; a cytotoxic effect against the National Collection of Type Cultures clone 1469 host cells was observed with $5.0 \%(\mathrm{w} / \mathrm{v})$ solution, $7.5 \%(\mathrm{w} / \mathrm{v})$ scrub, and $10.0 \%(\mathrm{w} / \mathrm{v})$ solution. Active PVP-I formulations in study 2 demonstrated effective virucidal activity against coronaviruses in less than $15 \mathrm{~s}$; $\log _{10}$ reduction in viral titer for each coronavirus strain was consistently higher for $10.0 \%$ $(\mathrm{w} / \mathrm{v})$ solution and $0.5 \%(\mathrm{w} / \mathrm{v})$ solution versus $7.5 \%(\mathrm{w} / \mathrm{v})$ scrub.

Conclusion: Both studies demonstrated in vitro virucidal activity of PVP-I formulations when challenged with SARS-CoV-2 surrogate coronaviruses. Although promising, further investigations are needed to evaluate SARS-CoV-2 inactivation. 
Keywords: Anti-infective agents; Coronavirus; Povidone-iodine; SARS-CoV-2; Virus inactivation

\section{Key Points}

\section{Why carry out the study?}

The coronavirus disease of 2019 (COVID19) pandemic underscores the need to supplement strategies to prevent virus transmission in home-based, community, and healthcare settings.

We assessed the virus inactivation effect of different povidone-iodine formulations, such as oral rinses, scrubs, and topical solutions, against surrogate viruses for severe acute respiratory syndrome coronavirus 2 (SARS-CoV-2) in two in vitro preclinical studies.

\section{What was learned from the study?}

Povidone-iodine demonstrated antiinfective activity, with all active formulations exhibiting effective in vitro virucidal activity.

These results provide further understanding of the virucidal activity of povidone-iodine and serve as a knowledge base for future studies, including those evaluating SARS-CoV-2 inactivation.

\section{INTRODUCTION}

Polyvinylpyrrolidone-iodine (povidone-iodine or PVP-I) is an antiseptic agent with broadspectrum anti-infective activity against a variety of pathogenic microorganisms, such as gramnegative and gram-positive bacteria, bacterial spores, fungi, protozoa, and viruses [1-4]. Virucidal activity against enveloped and non-enveloped viruses has been demonstrated [2, 5-7], with a short contact time relative to other commercially available antiseptic agents [7].
The efficacy and tolerability profile of PVP-I compared with that of other agents, such as chlorhexidine gluconate, polyhexanide, and octenidine, has been well established $[1-3,8]$. Regardless of clinical use spanning decades, there has been no or low documented resistance or cross-resistance [1-4]. Furthermore, the United States (US) Food and Drug Administration confirmed this position in its final rule on nonprescription antiseptic preparations intended for professional use in healthcare settings by not requiring resistance testing for certain active ingredients, including PVP-I [9]. This salient feature of PVP-I adds utility in the era of antimicrobial resistance. Various PVP-I formulations have been developed, including oral rinses, gargles, topical solutions, and surgical scrubs, and are available for topical or oral use in healthcare, dental, and household settings $[2-4,10]$.

Emergence of the novel severe acute respiratory syndrome coronavirus 2 (SARS-CoV-2) in 2019 and its spread globally over the following year have proven to be an unprecedented public health crisis [11]. At the peak, global daily cases were almost 1.5 million in December 2020, and global daily deaths were almost 18,000 in January 2021 [11]. The coronavirus disease of 2019 (COVID-19) pandemic has brought into focus the urgent need for effective physical interventions to mitigate virus transmission in homebased, community, and healthcare settings $[12,13]$, especially in the absence of definitive treatments and expanded access to available vaccines globally.

With a renewed focus on hand hygiene [12], evaluations of the virucidal activity of rinses, solutions, and scrubs have seen a significant uptake as the global community seeks to build an effective armamentarium against SARS-CoV2 . With respect to oral hygiene, PVP-I mouthwash was included in the list of non-drug experimental therapies against SARS-CoV-2 early in the pandemic [14]. Several in vitro studies have evaluated PVP-I formulations against SARS-CoV-2 and other viruses, including the Ebola virus and Middle East respiratory syndrome coronavirus (MERS-CoV) [5, 6, 15-20]. PVP-I formulations have been evaluated for use in high-risk clinical 
procedures involving the oropharynx and nasopharynx or in surgical practice [21-23] as a means to supplement available strategies, such as personal protective equipment [24], and prevent or reduce virus transmission during the ongoing pandemic.

Herein, we report findings from two in vitro studies that assessed the virucidal activity of different PVP-I formulations compared with matching placebos against the alphacoronavirus and betacoronavirus genera, which are surrogates for SARS-CoV-2. Study 1 assessed the efficacy of different PVP-I formulations against murine betacoronavirus strain A59 using the American Society for Testing and Materials (ASTM) in vitro time-kill method. Study 2 evaluated the virucidal properties of different PVP-I formulations challenged with human betacoronavirus strain OC43, human alphacoronavirus strain NL63, and human alphacoronavirus strain 229E using a virucidal suspension test (i.e., ASTM in vitro time-kill method).

\section{METHODS}

\section{Study Design and Rationale}

Coronaviruses have originated from many different animal species, including bats, cattle, camels, civets, and rodents [25]. They are known to cause mild to serious respiratory, gastrointestinal, and neurological diseases. Efficient viral transmission appears to depend upon the viral proteins and unique cell surface receptor(s) on the invaded cell types. The present preclinical in vitro study was undertaken to better understand the broad-spectrum antiviral activity of PVP-I and to determine, if any, differential effectiveness for various PVP-I formulations against various coronavirus strains. In this study, the efficacy of different PVP-I formulations was compared with matching placebos against human and murine coronavirus surrogates for SARS-CoV-2.

\section{Test Formulations}

Different test formulations, including active PVP-I (Betadine ${ }^{\circledR}$, Avrio Health L.P., Stamford, USA) and placebo, were assessed: $0.5 \%(\mathrm{w} / \mathrm{v})$ solution, placebo $0.5 \%(\mathrm{w} / \mathrm{v})$ solution, $5.0 \%(\mathrm{w} /$ v) solution, $7.5 \%(\mathrm{w} / \mathrm{v})$ scrub, placebo $7.5 \%(\mathrm{w} /$ v) scrub, and $10.0 \%(\mathrm{w} / \mathrm{v})$ solution in study 1 and $0.5 \%(\mathrm{w} / \mathrm{v})$ solution, placebo $0.5 \%(\mathrm{w} / \mathrm{v})$ solution, $7.5 \%(\mathrm{w} / \mathrm{v})$ scrub, placebo $7.5 \%(\mathrm{w} / \mathrm{v})$ scrub, and $10.0 \%(\mathrm{w} / \mathrm{v})$ solution in study 2 .

\section{Virus Strains and Host Cells}

In study 1, murine coronavirus strain A59 (American Type Culture Collection [ATCC] ${ }^{\circledR}$ VR-764 ${ }^{\mathrm{TM}}$ ), a betacoronavirus from the same genus that includes SARS-CoV-1, SARS-CoV-2, and MERS-CoV, was used as a surrogate for SARS-CoV-2; the strain was sourced from Dr. Nerea Irigoyen (Department of Pathology, University of Cambridge, UK). Mouse hepatitis virus A59 was used as a surrogate test virus for SARS-CoV- 2 in study 1 since it is a representative member of the genus betacoronavirus within the subfamily Coronavirinae-2, of which SARS-CoV-2 is a member [26-28]. The National Collection of Type Cultures (NCTC) clone 1469 cells (ATCC ${ }^{\circledR}$ CCL-9.1 ${ }^{\text {TM}}$; newborn mouse liver cells) were used as host cells. In study 2 , test formulations were challenged with three human viral strains that served as surrogates for SARS-CoV-2 [29]: coronavirus strain OC43 (ZeptoMetrix Corp. \#0810024CF), coronavirus strain NL63 (ZeptoMetrix Corp. \#0810228CF), and coronavirus strain 229E $\left(\right.$ ATCC $^{\circledR}$ VR$740^{\mathrm{TM}}$ ). MRC-5 cells (ATCC ${ }^{\circledR}$ CCL- $171^{\mathrm{TM}}$; human lung fibroblast cells), Vero cells (ATCC ${ }^{\circledR}$ CCL-81 ${ }^{\mathrm{TM}}$; green monkey epithelial kidney cells), and HCT- 8 cells (ATCC $^{\circledR}$ CCL-244 ${ }^{\mathrm{TM}}$; human colon adenocarcinoma epithelial cells) were used as host cells.

\section{Facilities}

The assays were performed at separate facilities: study 1 at BluTest Laboratories Ltd., Glasgow, UK, and study 2 at BioScience Laboratories, Inc. (BSLI), Bozeman, Montana, USA. Standard 
equipment and supplies were used; calibration was in accordance with the standard operating procedure (SOP) of each facility. This article is based on in vitro studies and did not include research on human participants or animals performed by any of the authors.

\section{Preparation of Test Formulations, Virus Suspensions, and Host Cells}

For study 1, higher-concentration PVP-I formulations (i.e., $5.0 \%(\mathrm{w} / \mathrm{v})$ solution, $7.5 \%(\mathrm{w} / \mathrm{v})$ scrub, and $10.0 \%(\mathrm{w} / \mathrm{v})$ solution) were diluted 1:10 in sterile distilled water for neutralization validation and the in vitro time-kill assay; the remaining test formulations (i.e., $0.5 \%(\mathrm{w} / \mathrm{v})$ solution, placebo $0.5 \%(\mathrm{w} / \mathrm{v})$ solution, and placebo $7.5 \%(\mathrm{w} / \mathrm{v}) \mathrm{scrub})$ were used undiluted. For study 2 , all test formulations were used as received from the study sponsor; final test formulations had a concentration of $90 \%$.

Virus strains were propagated and stored per standard procedure for production of high-titer virus stock (BSLI SOP L-2102); aliquots of stock virus suspension stored at $-70^{\circ} \mathrm{C}$ were thawed before use. ATCC-obtained host cells were maintained as monolayers in disposable cell culture labware in accordance with standard procedure (BSLI SOP L-2084). Before testing, these cultures were seeded onto multiwell, cell culture-treated plates. Vero and HCT- 8 cell monolayers were $80-90 \%$ confluent and less than $48 \mathrm{~h}$ old before virus inoculation; MRC-5 cells were $80 \%$ confluent and approximately $51 \mathrm{~h}$ old. The growth medium (i.e., RPMI-1640 or 1X Eagle's Minimum Essential Medium with $10 \%$ fetal bovine serum and $1 \%$ antibiotic and $\mathrm{L}-$ glutamine) was replaced with the maintenance medium (i.e., RPMI-1640 or 1X Eagle's Minimum Essential Medium with 2\% fetal bovine serum and $1 \%$ antibiotic and L-glutamine) to support virus propagation.

\section{Assessment of Cytopathic/Cytotoxic Effect}

Cytopathic/cytotoxic effect in host cells was monitored to determine the lowest concentration of PVP-I that was noncytopathic and noncytotoxic.

\section{Neutralization Validation}

Neutralization validation was performed to confirm the effectiveness of the procedure in neutralizing the active virucidal component with each formulation; this was performed for the median tissue culture infective dose $\left(\mathrm{TCID}_{50}\right)$ input virus, positive control, negative control, and test formulations. Standard testing methods based on ASTM were employed. Neutralization was validated when virus recovery in the positive control matched that in the neutralized formulation.

\section{Virucidal Suspension Test Using the Time- Kill Method}

For study 1, triplicates were set up for each designated exposure time point. The first well contained $0.8 \mathrm{~mL}$ of the test formulation at a specific concentration and $0.1 \mathrm{~mL}$ of sterile water. The procedure was initiated when $0.1 \mathrm{~mL}$ of virus was added to this well and mixed. Samples were incubated for designated exposure times of $15 \mathrm{~s}, 30 \mathrm{~s}, 60 \mathrm{~s}$, and $5 \mathrm{~min}$. Upon the specified time indicated, a $0.1-\mathrm{mL}$ volume from the well was sampled and applied gently to the surface of a prepared MicroSpin S-400 HR column and eluted per manufacturer's instructions. The void volume eluent $(0.1 \mathrm{~mL})$ was applied to a well containing $0.9 \mathrm{~mL}$ of $5 \%$ bovine serum albumin in phosphate-buffered saline at $20 \pm 1{ }^{\circ} \mathrm{C}$ and incubated for $5 \mathrm{~min}$ at $20 \pm 1{ }^{\circ} \mathrm{C}$. Following incubation, $0.1 \mathrm{~mL}$ of the mixture was diluted in $0.9 \mathrm{~mL}$ of cell culture media before being serially diluted up to a concentration of $10^{-6}$ and plated per the standard $\mathrm{TCID}_{50}$ reads/calculations; results were recorded. Subsequent analyses were performed using the well-established Spearman-Kärber method of quantification [30]. Positive controls were set up alongside the test formulation being processed; the positive-control well contained $0.8 \mathrm{~mL}$ of cell culture media, $0.1 \mathrm{~mL}$ of sterile water, and $0.1 \mathrm{~mL}$ of the virus. Positive controls were assessed at $0 \mathrm{~s}$ and $5 \mathrm{~min}$; negative controls 
were assessed at $15 \mathrm{~s}$ and $5 \mathrm{~min}$. The negative control runs were identical to the test formulation runs, except water was substituted for the virus suspension.

For study 2, a virucidal suspension test based on ASTM E1052-11 (Standard Test Method to Assess the Activity of Microbicides against Viruses in Suspension) was also performed. A $0.5-\mathrm{mL}$ aliquot of test virus was added to $4.5 \mathrm{~mL}$ of undiluted test formulation to obtain a $90 \%$ $(w / v)$ concentration of the test formulation. The challenge virus suspension was exposed to the test formulation for the designated exposure times (i.e., $0[<15 \mathrm{~s}$ ], $15 \mathrm{~s}, 30 \mathrm{~s}, 60 \mathrm{~s}$, and $5 \mathrm{~min}$ ). Immediately after exposure, the test virus suspension was neutralized in Dey-Engley neutralizing broth, mixed thoroughly, and serially diluted in the maintenance medium. Each dilution was plated in four replicates.

\section{Analytical Methods}

Viral titers in both studies were determined using the quantal test (Spearman-Kärber method) [30] and expressed as TCID To $_{50}$ using the following formula: $\log$ TCID $_{50}=L-d(s-0.5)$ / inoculum volume, where $L$ is the negative $\log _{10}$ of the lowest dilution, $d$ is the difference between the dilution steps, and $s$ is the sum of proportions of the positive wells per test dilution. Reduction in test virus infectivity of each strain was calculated as the difference in $\log _{10} \mathrm{TCID}_{50} / \mathrm{mL}$ between the virus control and the test virus; this was done at the designated exposure times (i.e., $15 \mathrm{~s}, 30 \mathrm{~s}, 60 \mathrm{~s}$, and $5 \mathrm{~min}$ for study 1 and $0[<15 \mathrm{~s}], 15 \mathrm{~s}, 30 \mathrm{~s}, 60 \mathrm{~s}$, and 5 min for study 2). The percentage reduction was also calculated and reported.

\section{RESULTS}

\section{Study 1}

All test formulations were validated for neutralization across triplicates at $60 \mathrm{~s}$ exposure time (data not shown). Active PVP-I formulations demonstrated effective virucidal activity against the murine coronavirus strain A59 at
$15 \mathrm{~s}$ under test conditions. The mean $\log _{10}$ reductions in viral titer after exposure to test conditions are presented in Table 1 . Three of the PVP-I formulations (i.e., $0.5 \%(\mathrm{w} / \mathrm{v})$ solution, $5.0 \%(\mathrm{w} / \mathrm{v})$ solution, and $10.0 \%(\mathrm{w} / \mathrm{v})$ solution) demonstrated high virucidal activity against the murine coronavirus strain A59 at $15 \mathrm{~s}$, with a mean $\log _{10}$ reduction of greater than 4.56 or greater than $99.99 \%$ viral inactivation; this was lower for $7.5 \%(\mathrm{w} / \mathrm{v})$ scrub, which had a mean $\log _{10}$ reduction of greater than 3.56. Placebo $0.5 \%(\mathrm{w} / \mathrm{v})$ solution showed the lowest virucidal activity against the murine coronavirus strain A59 (mean $\log _{10}$ reduction of 0.17 at $15 \mathrm{~s}$ ). Mean $\log _{10}$ reductions in viral titer for all test formulations are illustrated in Fig. 1.

Cytotoxic effects against NCTC clone 1469 host cells were observed with some of the PVP-I formulations (i.e., $5.0 \%(\mathrm{w} / \mathrm{v})$ solution, $7.5 \%$ $(\mathrm{w} / \mathrm{v})$ scrub, and $10.0 \% \quad(\mathrm{w} / \mathrm{v})$ solution). Accordingly, these formulations were tested at 1:10 dilution instead as this was the lowest concentration of PVP-I that was noncytotoxic against NCTC clone 1469 host cells. Furthermore, $7.5 \%(\mathrm{w} / \mathrm{v})$ scrub showed a lower $\log _{10}$ reduction at 1:10 dilution.

The efficacy of positive and negative virus controls was also evaluated for each test formulation at exposure times of $0 \mathrm{~s}$ and $5 \mathrm{~min}$, and $15 \mathrm{~s}$ and $5 \mathrm{~min}$, respectively. The positive controls for all test formulations, including active and placebo, showed mean $\log _{10}$ reductions in infectivity of 6.00 at $0 \mathrm{~s}$ and 6.06 at $5 \mathrm{~min}$. For negative controls across all test formulations, no differences were observed in mean $\log _{10}$ reductions in infectivity for exposure at $15 \mathrm{~s}$ versus $5 \mathrm{~min}$; mean $\log _{10}$ reductions in infectivity of 1.50 were observed for $0.5 \%(\mathrm{w} /$ v) solution, placebo $0.5 \%(\mathrm{w} / \mathrm{v})$ solution, $5.0 \%$ $(\mathrm{w} / \mathrm{v})$ solution, and $10.0 \%(\mathrm{w} / \mathrm{v})$ solution; 2.50 for $7.5 \%(\mathrm{w} / \mathrm{v})$ scrub; and 3.50 for placebo $7.5 \%$ $(\mathrm{w} / \mathrm{v})$ scrub.

\section{Study 2}

All test formulations were validated for neutralization along with neutralizer toxicity controls (data not shown). Across test formulations, the three PVP-I formulations demonstrated 


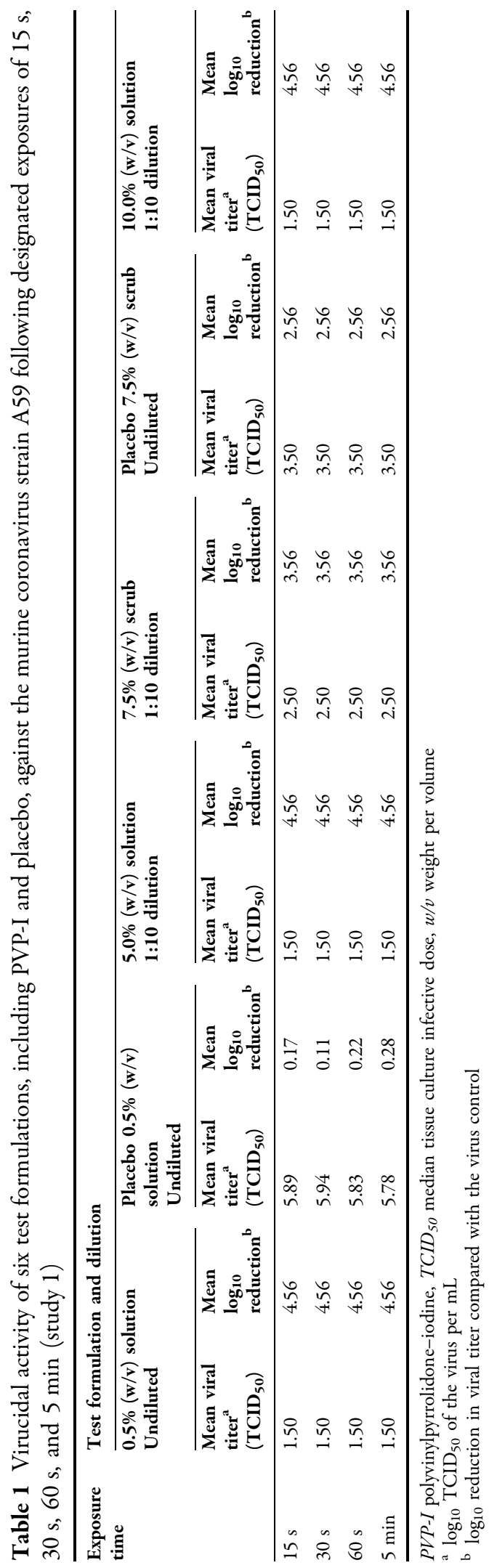




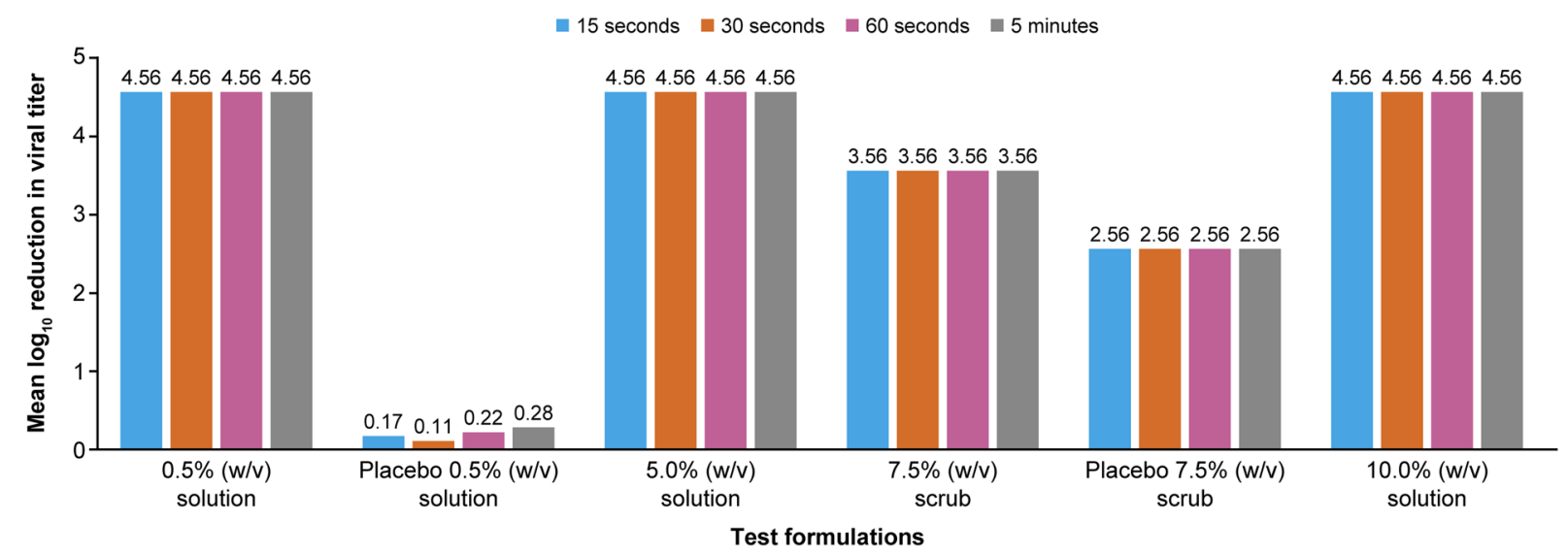

Fig. 1 Mean $\log _{10}$ reductions in viral titer as a function of exposure time for the six test formulations, including PVP-I and placebo (study 1). PVP-I polyvinylpyrrolidone-iodine, $w / v$ weight per volume

effective virucidal activity against the coronavirus strains in less than $15 \mathrm{~s}$, with mean $\log _{10}$ reduction in viral titers and some variability by PVP-I formulation and coronavirus strain; the infective dose and mean $\log _{10}$ reductions in viral titer after exposure to test conditions are presented in Table 2 . The $0.5 \%(\mathrm{w} / \mathrm{v})$ solution reduced the infectivity of all three coronavirus strains; the mean $\log _{10}$ reduction was the highest within $15 \mathrm{~s}$ of exposure for coronavirus strain NL63 (4.75 $\log _{10}$ or greater than $99.99 \%$ viral inactivation). The $10.0 \%(\mathrm{w} / \mathrm{v})$ solution also reduced the infectivity of all three coronavirus strains; the mean $\log _{10}$ reduction within $15 \mathrm{~s}$ of exposure was the highest for coronavirus strain NL63 (at least $5.25 \log _{10}$ or greater than $99.99 \%$ viral inactivation). Viral inactivation within $15 \mathrm{~s}$ across all coronavirus strains was the lowest for $7.5 \%(\mathrm{w} / \mathrm{v})$ scrub compared with the other active PVP-I formulations. The mean $\log _{10}$ reductions in viral titer for each coronavirus strain are illustrated in Fig. 2; these were consistently higher for $0.5 \%(\mathrm{w} / \mathrm{v})$ solution and $10.0 \%(\mathrm{w} / \mathrm{v})$ solution compared with $7.5 \%(\mathrm{w} / \mathrm{v})$ scrub and placebos.

Under the experimental conditions used, cytopathic or cytotoxic effect against host cells was observed for some test formulations: for coronavirus strain OC43, $0.5 \%(\mathrm{w} / \mathrm{v})$ solution for exposure of $0(<15 \mathrm{~s})$, placebo $0.5 \%(\mathrm{w} / \mathrm{v})$ solution for all exposure times, $7.5 \%(\mathrm{w} / \mathrm{v}) \mathrm{scrub}$ for all exposure times, placebo $7.5 \%(\mathrm{w} / \mathrm{v}) \mathrm{scrub}$ for all exposure times, and $10.0 \%(\mathrm{w} / \mathrm{v})$ solution for exposure of $0(<15 \mathrm{~s})$.

\section{DISCUSSION}

Though PVP-I has been shown to be a broadspectrum antiseptic agent, activity against murine and human coronavirus strains has not been previously reported in the literature. Our research using surrogate coronaviruses expands on the body of virucidal effectiveness data of PVP-I. Testing against surrogates helps inform several different research needs related to the novel coronavirus, including strain-to-strain comparisons, replicating test methods, and improving statistical confidence. Agent-surrogate comparison testing is also useful to ascertain if SARS-CoV-2 has unnatural environmental or antimicrobial persistence compared with other coronaviruses [31].

Our findings on virucidal activity were consistent with the results of other studies, including in vitro studies and an in vivo simulation study, of PVP-I formulations tested against viruses $[5,6,15,18,32]$, and an observed $\log _{10}$ reduction in the viral titer of at least 4, per European Standards of disinfectant efficacy [33]. PVP-I virucidal activity was observed within or at $15 \mathrm{~s}$ and persisted until $5 \mathrm{~min}$, the last measured exposure time in both studies, and was indicative of rapid and prolonged viral inactivation. Virucidal activity 


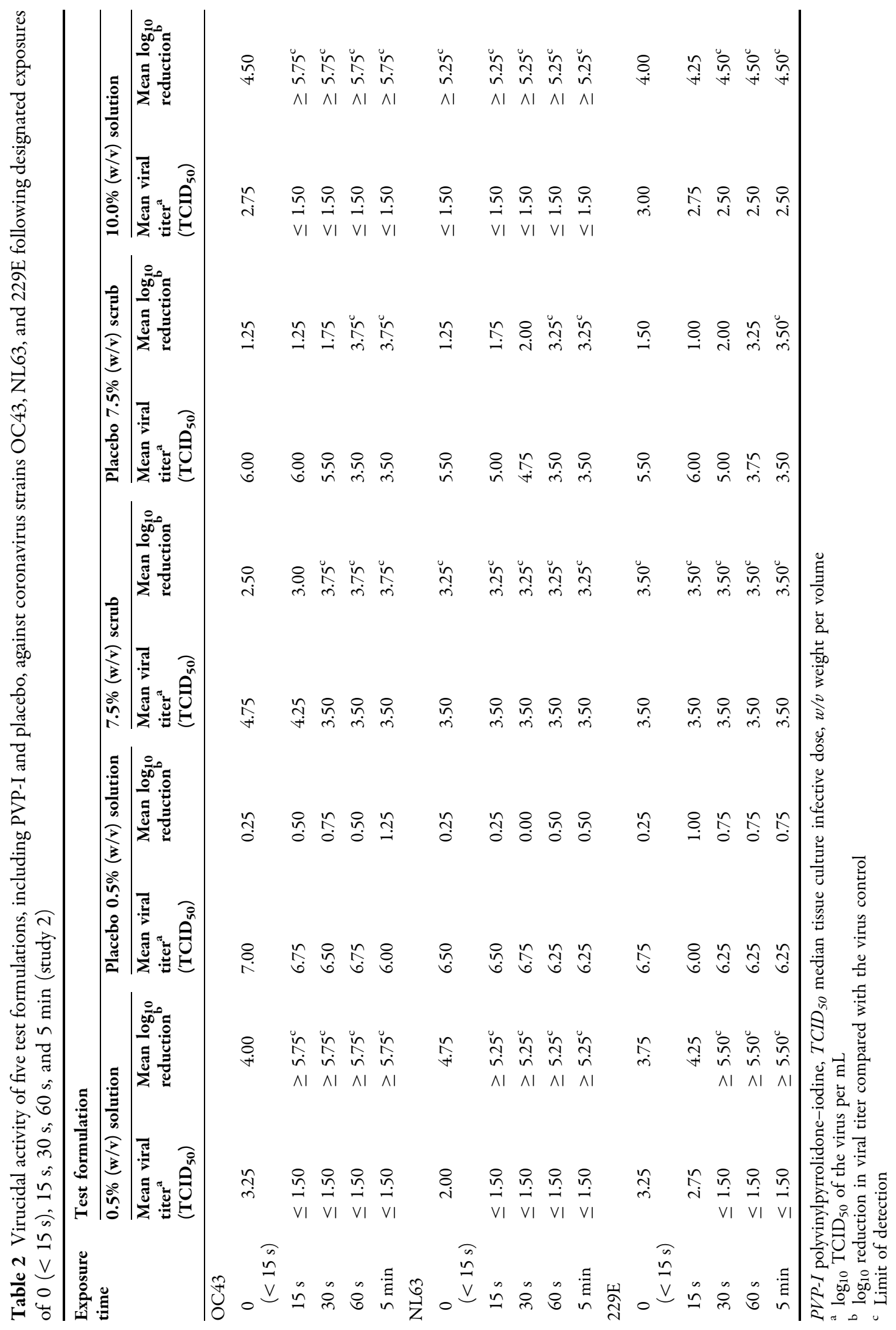


varied by PVP-I formulation: in study 1 , it was higher for $0.5 \%(\mathrm{w} / \mathrm{v})$ solution, $5.0 \%(\mathrm{w} / \mathrm{v})$ solution, and $10.0 \%(\mathrm{w} / \mathrm{v})$ solution against murine coronavirus strain A59 at designated exposure times compared with $7.5 \%(\mathrm{w} / \mathrm{v})$ scrub; in study 2 , it was consistently higher for $0.5 \%(\mathrm{w} / \mathrm{v})$ solution and $10.0 \%(\mathrm{w} / \mathrm{v})$ solution against three coronavirus strains compared with $7.5 \%(\mathrm{w} / \mathrm{v})$ scrub. It must be noted that $7.5 \%$ $(\mathrm{w} / \mathrm{v})$ scrub exhibited a lower $\log _{10}$ reduction (i.e., less than $4 \log _{10}$ reduction) at 1:10 dilution in study 1 compared with the other PVP-I formulations. This PVP-I formulation is designed as a sudsing cleanser for use in a medical/surgical setting. The sudsing is achieved through the inclusion of nonionic surfactants (e.g., nonoxynol-9). Following the mechanical action of handwashing, the cleanser and any associated pathogens are subsequently washed off the skin. Washing off the cleanser and associated pathogens in the clinical setting may be an important consideration in interpreting these in vitro study findings. Furthermore, it was hypothesized that some of the coformulant(s) may have contributed to host cell cytotoxicity as the undiluted placebo $7.5 \%(\mathrm{w} / \mathrm{v})$ scrub, which had the same formulation but without active PVP-I, also demonstrated similar cytotoxic effect against NCTC clone 1469 host cells, potentially leading to $\operatorname{lower} \log _{10}$ reduction values. In addition, since at least one of the nonionic surfactants in the formulation is known to exhibit microbicidal effects (e.g., nonoxynol-9) [34, 35], it is not surprising that the placebo $7.5 \%(\mathrm{w} / \mathrm{v})$ scrub exhibited some antiviral activity in these studies.

While recognized as safe and effective, there is a lack of clear consensus on US guidance related to benchmarks for virucidal efficacy testing (i.e., the magnitude of reduction in viral infectivity) [36]. Technical guidance has been established in Europe (i.e., European Standards or EN) to define requirements for test methods, including in vitro testing methods to ascertain the disinfectant efficacy [37] of agents such as PVP-I, and the magnitude of $\log _{10}$ reduction in viral titer (at least 4) [33, 38]. This benchmark is often reported as evidence of the efficacy of disinfectant activity and for comparison of results $[5,18]$, including for various antiseptic agents. In one study that included PVP-I, triclosan, chlorhexidine digluconate, octenidine dihydrochloride, and polyhexanide, the optimal efficacy of PVP-I was demonstrated over shorter and more immediate contact times of 1 min [39]. Another study assessed the bactericidal and virucidal efficacy of PVP-I [7.5\% (w/v) scalp and skin cleanser], chlorhexidine gluconate $[4.0 \%(\mathrm{w} / \mathrm{v})$ hand cleanser], and the reference handwash using the European Standard EN1499 and demonstrated a significantly higher mean $\log _{10}$ reduction with PVP-I compared with chlorhexidine gluconate for different volumes and contact times [32].

Physical interventions to reduce viral transmission during the current COVID-19 pandemic in healthcare, community, and homebased settings include maintaining hand hygiene by frequent and proper handwashing [12] and the use of personal protective measures $[14,24]$. In vitro studies of PVP-I using challenge testing have assessed virucidal efficacy, including against coronaviruses such as SARSCoV-2 [15-19]. In one study, all four PVP-I formulations $(10.0 \%(\mathrm{w} / \mathrm{v})$ antiseptic solution, $7.5 \%(\mathrm{w} / \mathrm{v})$ antiseptic skin cleanser, $1.0 \%(\mathrm{w} / \mathrm{v})$ gargle and mouthwash, and $0.45 \%(\mathrm{w} / \mathrm{v})$ throat spray) achieved at least $99.9 \%$ viral inactivation or at least a $4 \log _{10}$ reduction in viral titer within 30 s of contact [15]. In a study evaluating the in vitro virucidal activity of PVP-I gargle and mouthwash, the undiluted (PVP-I 1\% w/v) and 1:2 dilution (PVP-I $0.5 \% \mathrm{w} / \mathrm{v}$ ) formulations demonstrated rapid virucidal activity (at least $4 \log _{10}$ reduction in viral titer) at $15 \mathrm{~s}$ [18]. Although a gap exists in the interpretation of findings from in vitro studies and evidence from clinical studies is needed, effective anti-infective therapy has the potential to contribute significantly to ensuring safer healthcare and household environments, especially in the current pandemic.

Through our in vitro studies, we demonstrated the virucidal activity of a variety of PVP-I formulations, such as gargle/oral rinse, solution, and scrub, at different concentrations and with complementary uses in medical, dental, or surgical settings and personal care settings, when challenge tested against alphacoronavirus and betacoronavirus strains that served as surrogates 


\section{a. Coronavirus strain $\mathrm{OC} 43$}

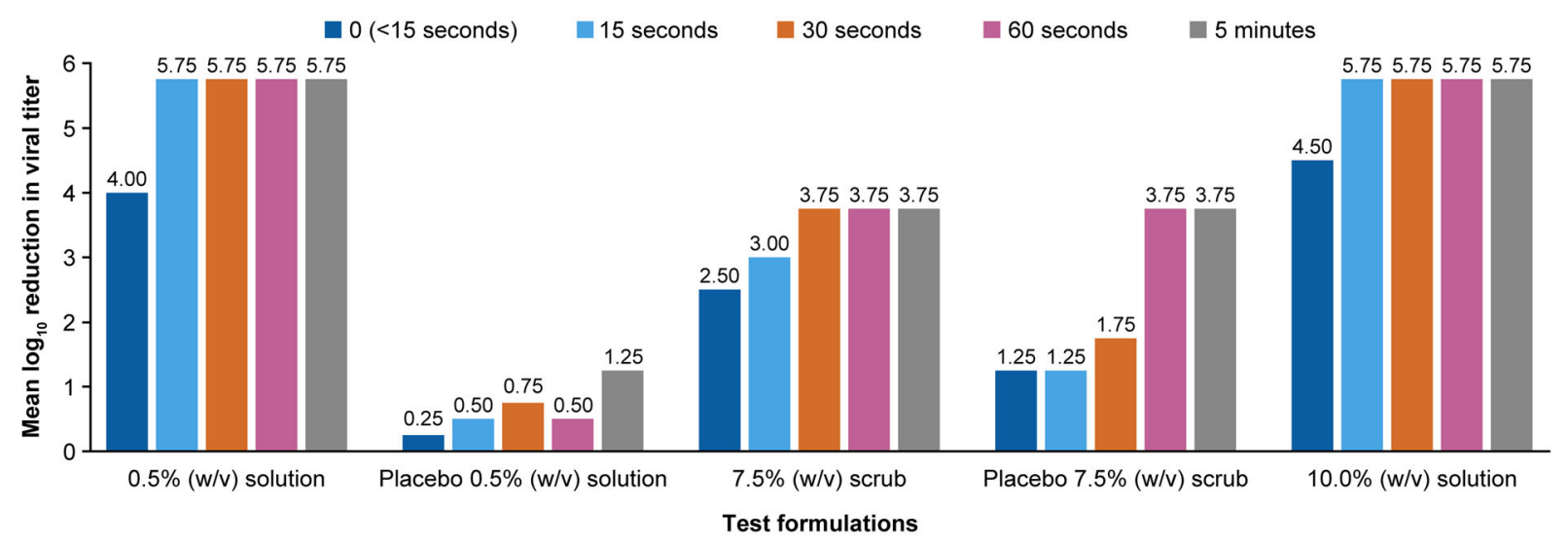

b. Coronavirus strain NL63

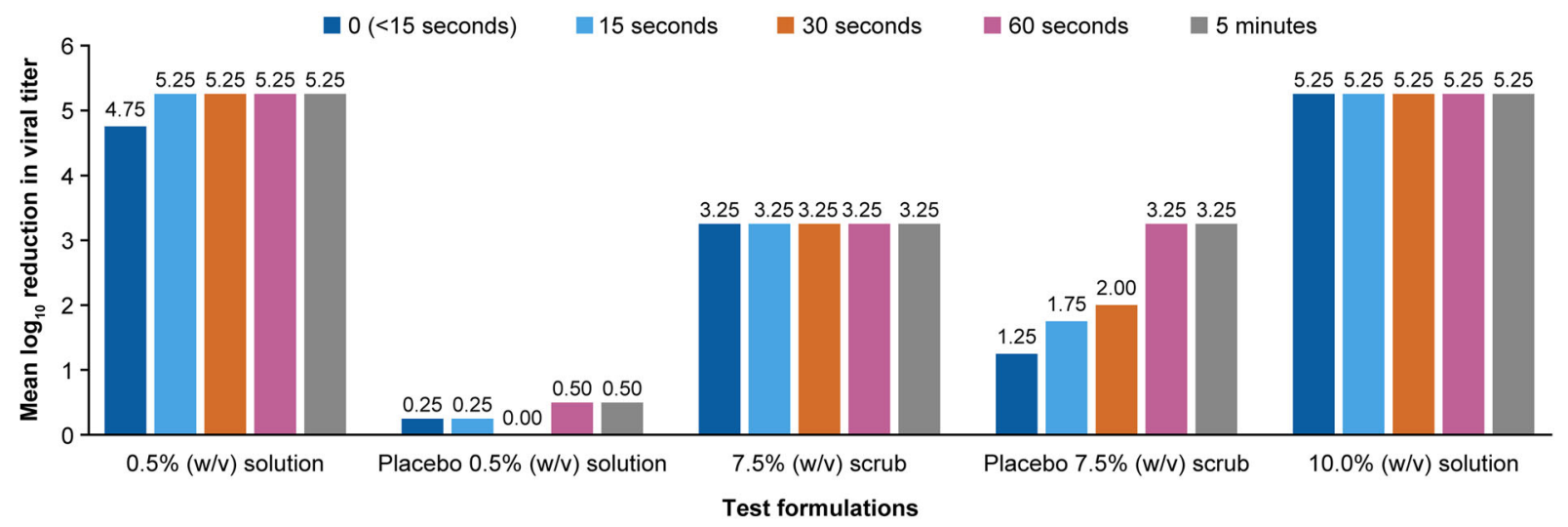

C. Coronavirus strain $229 \mathrm{E}$

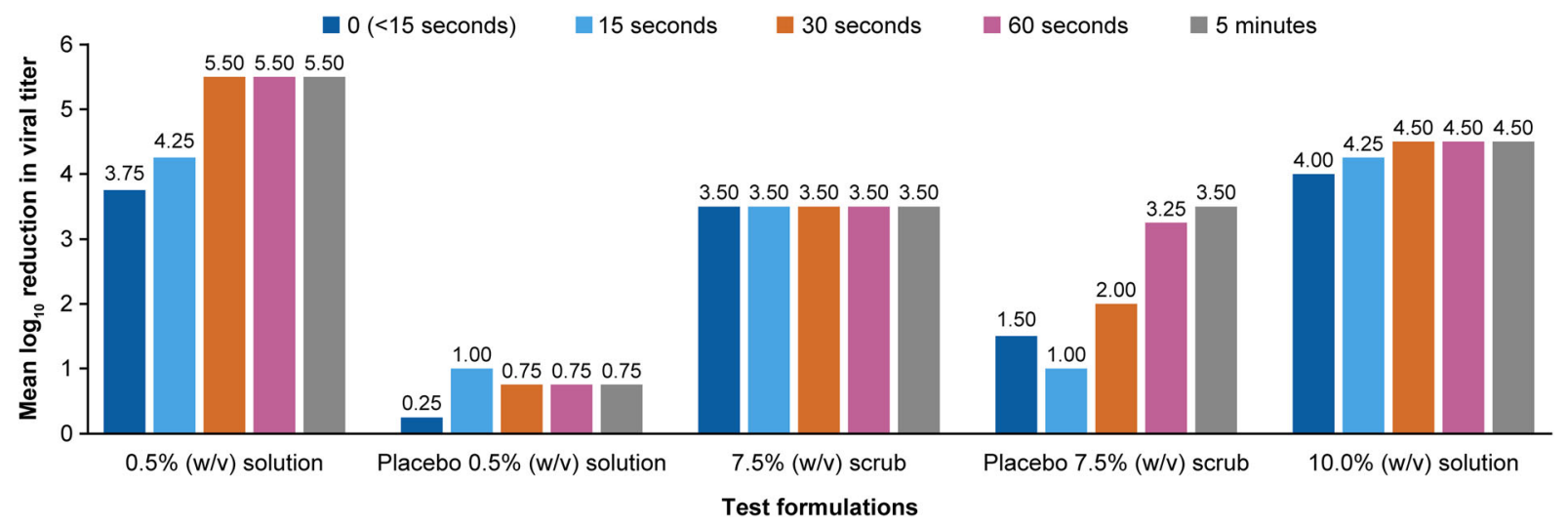

Fig. 2 Mean $\log _{10}$ reductions in viral titer as a function of exposure time for the five test formulations, including PVP-I and placebo (study 2). Coronavirus strains a OC43, b NL63, c 229E. PVP-I polyvinylpyrrolidone-iodine, w/v weight per volume

for SARS-CoV-2. It is encouraging to see recent preclinical and clinical evidence demonstrating PVP-I-mediated in vitro inactivation of SARSCoV-2 [40-45] as well as reduction in viral load using PVP-I oral formulations in randomized clinical trials on patients with COVID-19 $[46,47]$. Our findings and studies by other groups, together, strengthen the evidence for 
implementing the use of various PVP-I formulations in medical and personal care settings against a family of coronavirus strains, including SARS-CoV-2, as a broad-spectrum virucidal agent that neutralizes human and murine coronaviruses, potentially informing behaviors and preventing transmission during future pandemics. In these unprecedented times, the ongoing research using PVP-I provides additional safeguards to enhance existing preventive strategies and increase our armamentarium to prevent and reduce SARS-CoV-2 transmission in medical and community settings. To prevent virus transmission among patients, healthcare workers, and caregivers during the COVID-19 pandemic, future clinical studies on PVP-I effectiveness should include evaluation of the following: virucidal activity against SARS-CoV2; optimal delivery methods or formulations, including oral rinse, intranasal spray, or scrub; and optimal concentrations of different formulations for SARS-CoV-2 inactivation. Our study has some limitations. First, the in vitro nature of the study design prevents clinical interpretation of the findings. Second, there is a paucity of US standards for evaluating the in vitro virucidal efficacy of anti-infective agents against an established benchmark related to the magnitude of $\log _{10}$ reduction in viral titer and infectivity. Such a benchmark would provide a much-needed tool to evaluate the virucidal activity or efficacy of disinfectants.

\section{CONCLUSION}

Both studies demonstrated the in vitro virucidal activity of different PVP-I formulations against coronaviruses using the time-kill method. While these in vitro findings are promising, they should serve as a basis for clinically focused investigations to generate evidence on optimal concentrations and delivery methods and to evaluate the virucidal activity of PVP-I formulations against SARS-CoV-2.

\section{ACKNOWLEDGEMENTS}

The authors thank the participating staff at the two testing facilities, i.e., BluTest Laboratories Ltd., Glasgow, UK, and BioScience Laboratories, Inc., Bozeman, Montana, USA, for their contributions to the two in vitro studies.

Funding. The research (i.e., study 1 and study 2) was funded by Imbrium Therapeutics L.P., a subsidiary of Purdue Pharma L.P. Manuscript development, including medical writing support, and Rapid Service Fee were funded by Avrio Health L.P., a subsidiary of Purdue Pharma L.P., Stamford, Connecticut, USA. The sponsor was involved in study design; the collection, analysis, and interpretation of data; the writing of the article; and the decision to submit the article for publication.

Medical Writing and Editorial Assistance. Medical writing assistance in the preparation of this article was provided by Melissa Furtado, MPH, and Juliane Moloney, PhD, of Cactus Life Sciences (part of Cactus Communications). Editorial assistance was provided by Cactus Life Sciences (part of Cactus Communications). Support for medical writing and editorial assistance was provided by Avrio Health L.P., a subsidiary of Purdue Pharma L.P.

Authorship. All named authors meet the International Committee of Medical Journal Editors (ICMJE) criteria for authorship for this article, take responsibility for the integrity of the work as a whole, and have given their approval for this version to be published.

Author Contributions. Manjunath Shet contributed to investigation, writing-original draft, writing - review and editing, and project administration. Rosa Hong contributed to conceptualization, writing-original draft, and writing-review and editing. David Igo contributed to resources, writing-original draft and writing-review and editing. Marc Cataldo contributed to writing-original draft and writing-review and editing. Sailaja Bhaskar contributed to conceptualization, writing-original draft, writing-review and editing, 
and supervision. All authors approved the final draft of the submitted manuscript.

List of Investigators. Dr. Christopher Woodall (Study Director for study 1) and Dr. Volha Teagle (Study Director for study 2).

Disclosures. All authors, i.e., Manjunath Shet, Rosa Hong, David Igo, Marc Cataldo, and Sailaja Bhaskar, are employees of either the company that markets and distributes Betadine ${ }^{\circledR}$ (povidone-iodine) antiseptic products (Avrio Health L.P.), the parent company (Purdue Pharma L.P.), or another subsidiary company of Purdue Pharma (Imbrium Therapeutics L.P.).

Compliance with Ethics Guidelines. This article is based on in vitro studies and did not include research on human participants or animals performed by any of the authors.

Data Availability. The data that support the findings of the two in vitro studies are included in this published article. Further information about datasets generated and/or analyzed during the two in vitro studies may be available for non-commercial purposes from the corresponding author on reasonable request.

Open Access. This article is licensed under a Creative Commons Attribution-NonCommercial 4.0 International License, which permits any non-commercial use, sharing, adaptation, distribution and reproduction in any medium or format, as long as you give appropriate credit to the original author(s) and the source, provide a link to the Creative Commons licence, and indicate if changes were made. The images or other third party material in this article are included in the article's Creative Commons licence, unless indicated otherwise in a credit line to the material. If material is not included in the article's Creative Commons licence and your intended use is not permitted by statutory regulation or exceeds the permitted use, you will need to obtain permission directly from the copyright holder. To view a copy of this licence, visit http://creativecommons.org/licenses/by$\mathrm{nc} / 4.0 /$.

\section{REFERENCES}

1. Barreto R, Barrois B, Lambert J, Malhotra-Kumar S, Santos-Fernandes V, Monstrey S. Addressing the challenges in antisepsis: focus on povidone iodine. Int J Antimicrob Agents. 2020;56:106064. https:// doi.org/10.1016/j.ijantimicag.2020.106064.

2. Eggers M. Infectious disease management and control with povidone iodine. Infect Dis Ther. 2019;8:581-93. https://doi.org/10.1007/s40121019-00260-x.

3. Lachapelle J-M, Castel O, Casado AF, et al. Antiseptics in the era of bacterial resistance: a focus on povidone iodine. Future Med. 2013;10:579-92.

4. Williamson DA, Carter GP, Howden BP. Current and emerging topical antibacterials and antiseptics: agents, action, and resistance patterns. Clin Microbiol Rev. 2017;30:827-60. https://doi.org/10. 1128/CMR.00112-16.

5. Eggers M, Eickmann M, Kowalski K, Zorn J, Reimer K. Povidone-iodine hand wash and hand rub products demonstrated excellent in vitro virucidal efficacy against Ebola virus and modified vaccinia virus Ankara, the new European test virus for enveloped viruses. BMC Infect Dis. 2015;15:375. https://doi.org/10.1186/s12879-015-1111-9.

6. Eggers M, Eickmann M, Zorn J. Rapid and effective virucidal activity of povidone-iodine products against Middle East respiratory syndrome coronavirus (MERS-CoV) and modified Vaccinia virus Ankara (MVA). Infect Dis Ther. 2015;4:491-501. https://doi.org/10.1007/s40121-015-0091-9.

7. Kawana R, Kitamura T, Nakagomi O, et al. Inactivation of human viruses by povidone-iodine in comparison with other antiseptics. Dermatol. 1997;195(Suppl 2):29-35. https://doi.org/10.1159/ 000246027.

8. Kampf G, Todt D, Pfaender S, Steinmann E. Persistence of coronaviruses on inanimate surfaces and their inactivation with biocidal agents. J Hosp Infect. 2020;104:246-51. https://doi.org/10.1016/j. jhin.2020.01.022.

9. Food and Drug Administration, Health and Human Services. Safety and effectiveness of health care antiseptics; topical antimicrobial drug products for over-the-counter human use (Docket No. FDA2015-N-0101; final rule). Fed Reg. 2017;82: 60474-503.

10. Leaper DJ, Durani P. Topical antimicrobial therapy of chronic wounds healing by secondary intention using iodine products. Int Wound J. 2008;5:361-8. https://doi.org/10.1111/j.1742-481X.2007.00406.x. 
11. Johns Hopkins University. Coronavirus Resource Center. 2021. https://coronavirus.jhu.edu/map. html. Accessed 21 Apr 2021.

12. World Health Organization. SAVE LIVES: Clean Your Hands Campaign. WHO. 2020. https://www. who.int/campaigns/save-lives-clean-your-hands. Accessed 13 Jan 2021.

13. Ran L, Chen X, Wang Y, Wu W, Zhang L, Tan X. Risk factors of healthcare workers with coronavirus disease 2019: a retrospective cohort study in a designated hospital of Wuhan in China. Clin Infect Dis. 2020;71:2218-21. https://doi.org/10.1093/cid/ ciaa287.

14. World Health Organization. COVID 19 landscape of experimental treatments. WHO. 2020. https:// www.who.int/publications/i/item/covid-19. landscape-of-experimental-treatments. Accessed 4 Jan 2021.

15. Anderson DE, Sivalingam V, Kang AEZ, et al. Povidone-iodine demonstrates rapid in vitro virucidal activity against SARS-CoV-2, the virus causing COVID-19 disease. Infect Dis Ther. 2020;9:669-75. https://doi.org/10.1007/s40121-020-00316-3.

16. Bidra AS, Pelletier JS, Westover JB, Frank S, Brown SM, Tessema B. Rapid in-vitro inactivation of severe acute respiratory syndrome coronavirus 2 (SARS$\mathrm{CoV}-2$ ) using povidone-iodine oral antiseptic rinse. J Prosthodont. 2020;29:529-33. https://doi.org/10. 1111/jopr.13209.

17. Frank S, Brown SM, Capriotti JA, Westover JB, Pelletier JS, Tessema B. In vitro efficacy of a povidone-iodine nasal antiseptic for rapid inactivation of SARS-CoV-2. JAMA Otolaryngol Head Neck Surg. 2020;146:1054-8. https://doi.org/10.1001/jamaoto. 2020.3053 .

18. Hassandarvish $\mathrm{P}$, Tiong V, Mohamed NA, et al. In vitro virucidal activity of povidone iodine gargle and mouthwash against SARS-CoV-2: implications for dental practice. Br Dent J. 2020;228:900. https:// doi.org/10.1038/s41415-020-2402-0.

19. Pelletier JS, Tessema B, Frank S, Westover JB, Brown SM, Capriotti JA. Efficacy of povidone-iodine nasal and oral antiseptic preparations against severe acute respiratory syndrome-coronavirus 2 (SARSCoV-2). Ear Nose Throat J. 2021;100(2_suppl): 192S-196S.

0145561320957237.

20. Siddharta A, Pfaender S, Vielle NJ, et al. Virucidal activity of World Health Organization-recommended formulations against enveloped viruses, including Zika, Ebola, and emerging coronaviruses. J Infect Dis. 2017;215:902-6. https://doi.org/10. 1093/infdis/jix046.
21. Khan MM, Parab SR, Paranjape M. Repurposing 0. $5 \%$ povidone iodine solution in otorhinolaryngology practice in Covid 19 pandemic. Am J Otolaryngol. 2020;41:102618. https://doi.org/10.1016/ j.amjoto.2020.102618.

22. Mohamed NA, Baharom N, Wan Sulaiman WS, et al. Early viral clearance among COVID-19 patients when gargling with povidone-iodine and essential oils: a clinical trial. Int Med J. 2020;27: 651-4. https://doi.org/10.1101/2020.09.07. 20180448.

23. Yan $\mathrm{CH}$, Bleier BS. Prophylactic and therapeutic topical povidone-iodine in coronavirus disease 2019 (COVID-19): what is the evidence? Int Forum Allergy Rhinol. 2020;10:1271-3. https://doi.org/10. 1002/alr.22735.

24. Mady LJ, Kubik MW, Baddour K, Snyderman CH, Rowan NR. Consideration of povidone-iodine as a public health intervention for COVID-19: utilization as "Personal Protective Equipment" for frontline providers exposed in high-risk head and neck and skull base oncology care. Oral Oncol. 2020;105: 104724. https://doi.org/10.1016/j.oraloncology. 2020.104724 .

25. Corman VM, Muth D, Niemeyer D, Drosten C. Hosts and sources of endemic human coronaviruses. Adv Virus Res. 2018;100:163-88. https:// doi.org/10.1016/bs.aivir.2018.01.001.

26. Cui W, Cui S, Chen C, et al. The crystal structure of main protease from mouse hepatitis virus A59 in complex with an inhibitor. Biochem Biophys Res Commun. 2019;511:794-9. https://doi.org/10. 1016/j.bbrc.2019.02.105.

27. Lissenberg A, Vrolijk MM, van Vliet ALW, et al. Luxury at a cost? Recombinant mouse hepatitis viruses expressing the accessory hemagglutinin esterase protein display reduced fitness in vitro. J Virol. 2005;79:15054-63. https://doi.org/10.1128/ JVI.79.24.15054-15063.2005.

28. Yang Z, Du J, Chen G, et al. Coronavirus MHV-A59 infects the lung and causes severe pneumonia in C57BL/6 mice. Virol Sin. 2014;29:393-402. https:// doi.org/10.1007/s12250-014-3530-y.

29. Chakraborty A, Diwan A. NL63: a better surrogate virus for studying SARS-CoV-2. Integr Mol Med. 2020;7:1-9. https://doi.org/10.15761/IMM. 1000408 .

30. Ramakrishnan MA. Determination of 50\% endpoint titer using a simple formula. World J Virol. 2016;5:85-6. https://doi.org/10.5501/wjv.v5.i2.85.

31. Guidance on SARS-CoV-2 surrogate selection (ASTM standard under consideration). ASTM. 2020. 
https://www.astm.org/COMMIT/

GuidanceCOVID19SurrogateSel_April242020press. pdf. Accessed 10 Sep 2021.

32. Eggers M, Koburger-Janssen T, Ward LS, Newby C, Müller S. Bactericidal and virucidal activity of povidone-iodine and chlorhexidine gluconate cleansers in an in vivo hand hygiene clinical simulation study. Infect Dis Ther. 2018;7:235-47. https://doi.org/10.1007/s40121-018-0202-5.

33. European Committee for Standardization. EN 14476:2013+A2:2019 Chemical disinfectants and antiseptics-quantitative suspension test for the evaluation of virucidal activity in the medical area-test method and requirements (Phase 2/Step 1). 2019. https://standards.iteh.ai/catalog/ standards/cen/10065fd9-2d40-4f02-bccd-

48206b72f108/en-14476-2013a2-2019. Accessed 10 Sept 2021.

34. Hooton TM, Fennell CL, Clark AM, Stamm WE. Nonoxynol-9: differential antibacterial activity and enhancement of bacterial adherence to vaginal epithelial cells. J Infect Dis. 1991;164:1216-9. https://doi.org/10.1093/infdis/164.6.1216.

35. Klebanoff SJ. Effects of the spermicidal agent nonoxynol-9 on vaginal microbial flora. J Infect Dis. 1992;165:19-25. https://doi.org/10.1093/infdis/ 165.1.19.

36. US Food and Drug Administration. FDA letter regarding deferral of povidone-iodine. 2017. https://www.regulations.gov/document?D=FDA2015-N-0101-1326. Accessed 7 Jan 2021.

37. Suchomel M, Kundi M, Pittet D, Rotter ML. Modified World Health Organization hand rub formulations comply with European efficacy requirements for preoperative surgical hand preparations. Infect Control Hosp Epidemiol. 2013;34: 245-50. https://doi.org/10.1086/669528.

38. Suchomel M, Steinmann J, Kampf G. Efficacies of the original and modified World Health Organization-recommended hand-rub formulations. J Hosp Infect. 2020;106:264-70. https://doi.org/10.1016/j. jhin.2020.08.006.

39. Koburger T, Hübner N-O, Braun M, Siebert J, Kramer A. Standardized comparison of antiseptic efficacy of triclosan, PVP-iodine, octenidine dihydrochloride, polyhexanide and chlorhexidine digluconate. J Antimicrob Chemother. 2010;65: 1712-9. https://doi.org/10.1093/jac/dkq212.
40. Davies K, Buczkowski H, Welch SR, et al. Effective in vitro inactivation of SARS-CoV-2 by commercially available mouthwashes. J Gen Virol. 2021;102: https://doi.org/10.1099/jgv.0.001578.

41. Xu C, Wang A, Hoskin ER, et al. Differential effects of antiseptic mouth rinses on SARS-CoV-2 infectivity in vitro. Pathogens. 2021;10:272. https://doi. org/10.3390/pathogens10030272.

42. Hassandarvish P, Tiong V, Mohamed NA, et al. In vitro virucidal activity of povidone iodine gargle and mouthwash against SARS-CoV-2: implications for dental practice. Br Dent J. 2020. https://doi.org/ 10.1038/s41415-020-2402-0.

43. Anderson DE, Sivalingam V, Kang AEZ, et al. Povidone-iodine demonstrates rapid in vitro virucidal activity against SARS-CoV-2, the virus causing COVID-19 disease. Infect Dis Ther. 2020;9:669-75. https://doi.org/10.1007/s40121-020-00316-3.

44. Bidra AS, Pelletier JS, Westover JB, Frank S, Brown SM, Tessema B. Rapid in-vitro inactivation of severe acute respiratory syndrome coronavirus 2 (SARSCoV-2) using povidone-iodine oral antiseptic rinse. J Prosthodont. 2020;29:529-33. https://doi.org/10. 1111/jopr.13209.

45. Tadakamadla J, Boccalari E, Rathore V, Dolci C, Tartaglia GM, Tadakamadla SK. In vitro studies evaluating the efficacy of mouth rinses on Sars-Cov2: a systematic review. J Infect Public Health. 2021;14:1179-85. https://doi.org/10.1016/j.jiph. 2021.07.020.

46. Guenezan J, Garcia M, Strasters D, et al. Povidone iodine mouthwash, gargle, and nasal spray to reduce nasopharyngeal viral load in patients with COVID-19: a randomized clinical trial. JAMA Otolaryngol Head Neck Surg. 2021;147:400-1. https:// doi.org/10.1001/jamaoto.2020.5490.

47. Seneviratne CJ, Balan P, Ko KKK, et al. Efficacy of commercial mouth-rinses on SARS-CoV-2 viral load in saliva: randomized control trial in Singapore. Infection. 2021;49:305-11. https://doi.org/10. 1007/s15010-020-01563-9.

\section{Publisher's Note}

Springer Nature remains neutral with regard to jurisdictional claims in published maps and institutional affiliations. 